\title{
Ethnic Insularity among 1.5- and Second-Generation Korean-American Christians*
}

\author{
JERRY Z. PARK | BAYLoR UnIVERSITY
}

Building on insights from Min's (2010) comparisons between Korean Protestants and Indian Hindus, and my findings of elite freshmen Korean racial insularity (Park 2012), I use data from the Immigration and Intergenerational Mobility in Metropolitan Los Angeles (2004) survey to examine the extent to which religion serves to not only preserve ethnicity but also support insularity in young adult 1.5- and second-generation ("second generation" hereafter) Korean Americans. Findings suggest that at the racial level of comparison, second-generation Korean-American endogamy resembles that of white, black, and Latino endogamy; second-generation Korean-American endogamy reflects not only the highest intraracial marriage rate, but also the highest intraethnic marriage rate of all Asian groups in the sample. Further, religious married second-generation Korean Americans have the highest racially homogeneous composition rate in the congregations they attend relative to other racial groups and other Asian ethnicities. In multivariate analyses, these two dynamics of marital endogamy and congregational racial homophily produce strong effects on one another and diminish the unique Korean effect. Findings suggest that these group relational patterns are more evident for second-generation Korean Americans and may have implications for social mobility in a racialized context.

Keywords: Second-Generation Korean Protestants, Second-Generation Asian Americans, Religious Preferences, Intermarriage, Religious Congregations, Racial Homophily

\footnotetext{
*This paper was originally presented at the Fourth Annual Conference of the Research Center for Korean Community at Queens College CUNY, April 5-7, 2013. Special thanks to Thomas Chung for editorial assistance.
} 


\section{Introduction}

In an ever-pluralizing environment, the need for understanding social integration between various groups grows more urgent and more complex. Immigration continues apace and recent reports show that Asia is now the largest sending continent, followed closely by Latin America (Taylor et al. 2012). With lower population growth among non-Hispanic whites, the United States increasingly resembles the racial pentagon proposed by David Hollinger (1995): White, Black, Hispanic, Asian, and Native American. One of the key players in the new multicultural drama is the children of immigrants, the second generation. Being born and/or raised in the United States, these Latino and Asian young Americans play an important role in understanding how well social integration occurs today. In the following study, I introduce current research on racial integration and apply them to a large sample of second-generation young adult Americans in the Los Angeles area, with particular attention to the second-generation Korean-American Protestant case. The intersection of racial minority status and conservative Protestant status suggest a lack of integration or greater insularity, but for different reasons.

Milton Gordon first systematized the ways in which new Americans assimilate into society and offered a seven-stage process by which new groups are integrated into the mainstream of U.S. society. Of particular importance for this study are the second and third stages, which he describes as structural and marital assimilation. Structural assimilation refers to the large-scale integration of ethnic and racial groups into mainstream organizations, such as clubs and institutions. Marital assimilation refers to ethnically or racially mixed marriages. Greater proportions of new ethnic groups in the main institutions of society, as well as marrying members of the dominant group, indicate these two stages of assimilation. Since the time of Gordon's writing, new immigration to the U.S. has seen an unprecedented growth of Asian and Latino sojourners who, alongside African Americans, now constitute more than 35 percent of all Americans today. Given these new racialized realities, how well do Gordon's theorizing (built on observations of early $20^{\text {th }}$ century immigration) hold? 


\section{Racial and Religious Socialization of the Second Generation}

As children of immigrants, the second generation faces a variety of competing socialization influences on how they define their self and group identities. Chief among these is racial and ethnic socialization. For most contemporary immigrants in the United States, their physical appearance marks them as non-white in the current racial categorization scheme. Coupled with these perceived differences are the cultural norms and languages that distinguish ethnic groups from one another. Hence a secondgeneration individual may be racially Asian and ethnically Korean, and one learns this through family relations and (where available) an ethnic community.

Ethnic communities for new immigrants often take the form of an ethno-religious community. As a source of social and spiritual support, many immigrants today turn to a local congregation of like-minded ethnic members (Min 1992). One of the important functions of these religious communities is transmission of the culture of the first generation to the second generation. But is it ethnic culture or religious culture that is transmitted? In a recent study, Min (2010) finds that transference of culture varies considerably by the combination of ethnicity and religion of the group in question. In his study of Korean Protestants and Indian Hindus in the New York area, it is religious culture that appears to transfer most readily for the former and ethnic culture for the latter. As he argues, these differences stem from the degree of dogmatic authoritarianism embedded in the religious belief system one adheres to. For Korean Protestants, their faith is one that is highly exclusive and non-porous, which leaves out the incorporation of their ethnic culture. This does not render their religious faith "cultureless;" the ethno-racial cultural norms and schemas tied to the Christianity that was introduced to Korean immigrants in the 1960s onward remain intact and subsumed into the theology and practice of the faith tradition. There are no specific Korean Protestant holy days observed, no specific practices that are uniformly practiced in Korean Protestant churches. Therefore, a Koreaninflected Protestantism is largely absent in the socialization of the second generation. By contrast, Hinduism, owing to its highly adaptable and porous beliefs, is much less dogmatic and authoritarian. Further, its ancient ties to the history of India combine together to produce a relatively weaker religious identity, but a stronger ethnic identity for many second-generation Indian Hindus. Focusing specifically on the second-generation Korean-American 
Protestant (SGKAP) case, I hypothesize:

H1: Given their background exposure to Korean immigrant Protestantism, SGKAPs will retain their faith tradition relative to other second-generation Asian American groups.

H2: Given the relative absence of Korean ethnic culture within KoreanAmerican Protestantism, SGKAPs will not be fluent in the Korean language relative to other second-generation Korean Americans.

\section{Racially Comfortable but Religiously White: Second-Generation Korean-American Protestant Dilemmas}

Given the lack of infusion of Korean culture into Korean-American Protestantism, it appears curious that numerous studies of the SGKAP case show high mono-ethnic religious participation (e.g. R. Y. Kim 2006, 2004; Park 2004). In one set of studies, these observations were made in the college context. ${ }^{1}$ The college experience of religious racial homogamy among SGKAPs is significant in part because the majority of second-generation Korean Americans attend higher education institutions relative to other nonAsian American groups. According to a report by the Pew Research Centers (2013), while 21 percent of second-generation Latinos aged 25 and older earned at least a bachelor's degree by 2012, 55 percent of second-generation Asian Americans exhibited the same attainment. Importantly, the presence of these racially-homogeneous religious student groups in some of our most prestigious and diverse universities contributes to the perception that AsianAmerican evangelicals play a significant role in the undergraduate experience of evangelicalism more generally.

According to sociologist Rebecca Kim, the key factors for mono-ethnic religious participation among SGKAPs are opportunity, racial homogamy, and early mono-ethnic socialization. At her site, a large public university in southern California, the Korean student population numbered in the thousands, and the Asian-American population extended well beyond onethird of the student body (but not the majority). The size of the KoreanAmerican population lends itself to the formation of numerous student

\footnotetext{
${ }^{1}$ See also Abelmann (2009); Park (2004); Park (2012); several studies have also examined the comparative participation of various second-generation Asian American Protestant groups (see Alumkal 2003; Ecklund 2006; Jeung 2005; Kim 2010).
} 
groups and many of them were evangelical Protestant. Second, homophily, or the preference for same-ness in group identification, is a truism in sociology. As such, in a highly racialized environment such as the United States, samerace preference among minority groups is common. This preference for same-race religious group presence is also affected by the shared socialization experience that many SGKAPs recall during their years growing up as the children of church-attending Korean immigrants. Drawing together Min's insights with Kim's, we find that while the content of SGKAP culture may hinder ethnic identity development, the near-exclusive ethnic immigrant church experience creates a preference for same-race, if not same-ethnic religious group participation. The religious content (both in the expression of belief and practice) of SGKAP college evangelicalism resembles white evangelicalism even though the group members themselves are largely Korean. From here we have preliminary evidence that suggests SGKAPs might be more inclined to participate in mono-ethnic or mono-racial churches once they graduate from college.

New research however extends these observations directly into the postcollege experience. Similar to Rebecca Kim's argument, sociologist Sharon Kim (2010) observes that SGKAP religious participation remains relatively high but the context in which that participation takes place does not align with what one might expect for those who were raised in a Protestantism that is devoid of their ethnic heritage. While SGKAPs participate much less in the congregations of their youth, many, perhaps most, are participating in congregations of fellow second-generation Korean, Asian, and multiracial peers (48). ${ }^{2}$ In her study of over 22 SGKAP congregations in southern California, Kim found that while second-generation ethnic identities do not readily reflect retention of their parents' culture, they nevertheless insist that they are uniquely Korean, specifically Korean American. For Kim this subtle distinction is the key effort in many SGKAP congregations: to create hybrid spaces in which evangelical-approved elements of Korean and mainstream white culture are fused together to create a new SGKAP spirituality. Given this particular niche effort and combining it with earlier insights I hypothesize:

H3: As a proximal measure for ethnicity, SGKAPs will attend Asiandominant churches relative to other religiously-affiliated second-generation Americans, where available.

\footnotetext{
${ }^{2}$ Other Asian Protestant groups experience similar marginalization (see Jeung 2005).
} 


\section{Intimate Integration: Interracial marriage}

Tied to religious group participation for young religious Americans, family reproduction is of vital importance. Most traditional religious communities, regardless of ethnicity, promote marriage and natality. In doing so religious communities ensure the growth and maintenance of their group. As Kalmijn (1998, p. 408) summarized, "Denominations and religions that are more traditional in religious doctrine and have higher degrees of church involvement among their members have the highest degree of endogamy". This preference for endogamy specifically refers to religious homogamy as opposed to ethnic or racial homogamy. In many cases the two might go hand in hand and perhaps correlate in the minds of some believers. Thus with respect to marital assimilation, the bundling of race or ethnicity with religion demands careful examination of the specific effects that promote boundarycrossing. In the following I summarize the major themes in the study of intermarriage and introduce new considerations of religious effects in the analysis of intermarriage.

Intermarriage is important, in part, because it reflects a shift in identification. The typical pattern of marriage is endogamy, to marry someone of one's own group (Blau 1977). Intermarriage therefore suggests a new self-identification whereby the definition of one's group is now reshaped to include groups who were not previously included in an individual's early socialization of group identity. In the U.S., the primary demarcation of group difference is race. But given the constructed nature of race, the definitions for an intergroup relationship varies from study to study. In some instances, race is conceptualized as including those of non-Hispanic white, black and Asian identification; others incorporate Latinos, arguing that interethnic difference should be accounted for in intermarriage analyses. When interethnic relationships are brought into the picture, differences among AsianAmerican groups as well as Latino groups further complicate what is meant by "intermarriage." This is particularly evident in the Asian- American intermarriage case; for example, Min and Kim (2009) find that when members of Asian ethnic groups marry exogamously, they do not marry different ethnic Asians primarily-they marry non-Hispanic whites. ${ }^{3}$ Given

\footnotetext{
${ }^{3}$ Arguably too, religious difference might also be conceived as "interethnic" to the extent that denominational difference functions as a salient social category and boundary maker. Due to data and space limitations I will not consider this possibility in our analyses.
} 
these inconsistencies in the literature, I include both interracial and interethnic relationships as forms of intermarriage.

One of the main factors in racial intermarriage is group size: since endogamy is the norm, larger groups should report lower exogamy rates while smaller groups should report larger exogamy rates, assuming that all other factors are equal. Not surprisingly, according to a report from the Pew Research Centers, non-Hispanic white Americans have the lowest intermarriage rate given their dominant numerical presence. By contrast, small groups such as Asian Americans and Native Americans have the highest intermarriage rates given that the available pool of marriage partners is much larger if they include groups that are not of their ethnic or racial background (Taylor et al. 2010). Notably, the rate of Asian and Latino intermarriage actually trended down due to an increasing rate of immigration from the 1990s onward (Qian and Lichter 2007, 2011). These more recent treatments of intermarriage incorporate Hispanic heritage as a unique racialized category of equal weight with the earlier "white, black, or Asian" distinctions.

\section{Second-Generation Interracial Marriage and Religion}

Measuring interracial marriage is complicated due to the variety of definitions which reflect the many ways that an exogamous relationship can be framed. Depending on the definition used, different processes explain the likelihood of intermarriage. For the purposes of this study, we limit intermarriage to those relationships involving at least one U.S.-born or U. S.-raised respondent. If intermarriage reflects straightline assimilation processes, we would expect that the second generation of Asian- and LatinAmerican interracial marriage might be higher relative to the first generation. Sociologist C. N. Le (2012) has shown this to be the case. ${ }^{4}$ Importantly, the rates vary by ethnic group and gender within each ethnic group. Among native-born Asian Americans, Min and Kim (2009) found in their analysis of the American Community Surveys 2001-2006 that U.S.-born Japanese Americans were the most exogamous, and that U.S.-born Asian Indians were the least. The fairly low exogamy rate for second-generation Asian Indians and the higher second-generation Korean exogamy rate comports with Min's (2010) argument regarding high ethnic identity retention for the former and low retention for the latter.

\footnotetext{
${ }^{4}$ http://www.asian-nation.org/interracial.shtml
} 
Religious affiliation bears some important influence for specific ethnic group intermarriage rates. For instance, Min and Kim (2009) argued that the higher exogamy rate of second-generation Filipinas is due in part to the relative scarcity of Filipino-dominant Catholic parishes. But this does not explain the high exogamy rate of second-generation Korean-American women. If religious supply is not a barrier, the exogamy rate might be explained by Min's thesis that Korean-American Protestantism inhibits ethnic attachment. Arguably then, the weak relationship between evangelicalism and Korean ethnicity is more pronounced for second-generation KoreanAmerican women. In both Filipino and Korean cases, where one religious tradition dominates local community cultures, religion appears to play an important role in interracial marriage.

One study has considered the role of religion in second-generation intermarriage outcomes. Using data from the Children of Immigrants Longitudinal Study, Charlie Morgan (2012) finds that young secondgeneration Catholics in southern California are the least likely to intermarry whether across ethnic or racial lines. Young second-generation Protestants, on the other hand, are the most likely to be in an interracial relationship, after accounting for a variety of background characteristics. Data limitations did not allow Morgan to link together religious dominance within specific ethnic groups and thus his findings reflect more broadly on the patterns of secondgeneration southern Californians. Nevertheless they point to the power of religious identity to constrain relationship choices along racial lines.

\section{Sacralizing, Rejecting, and Transcending Ethnicity}

Since religious traditions promote religious endogamy, its effect on racial intermarriage can follow several different pathways. For example, religious proscriptions toward homogamy might imply racial or ethnic exclusivity. One's lived experience with a religious community could entail racial or ethnic differentiation such that one associates religion with one's particular ethnicity. In a study of an evangelical Protestant immigrant church in Chicago, Kelly Chong (1998) provided evidence of sacralizing ethnicity in the religious socialization of SGKAPs. Korean immigrant evangelical Protestants promoted Korean cultural values as compatible with evangelical Protestant values; thus being Korean implied being Christian. ${ }^{5}$ Sharon Kim (2010)

\footnotetext{
${ }^{5}$ See also Rudy Busto (1996)'s essay on Asian American evangelical participation on college campuses; he similarly finds a sacralizing tendency of "Asian values" in these group contexts.
} 
furthers this observation for the second generation as they develop secondgeneration congregations in southern California. In many of these churches, Korean styles of Christian prayer are invoked as a means of sacralizing their ethnicity.

The other approach entails distinguishing ethnicity from religion. This can take several forms. As argued by Min, the most neutral form of decoupling religion from ethnicity is to minimize ethnic cultural associations with a faith tradition. A second form entails rejecting ethnicity in view of religious universality. This approach appears to be one advocated by some Asian-American Protestants of the second generation who employ religious discourse as a means of critiquing the ethnic cultural practice of the immigrant generation who share the same religion. One of the chief flashpoints in these debates is the position of women in religious leadership (Alumkal 1999; Muse 2005; Yang 2004). Finally, religious identity could supplant or replace ethnic identity. Drawing from Gerardo Marti's (2005) concept of ethnic transcendence, religious groups can acknowledge the significance of ethnic and racial identity but subsume those identities under the larger universal identity of a shared Christian faith.

From these we can surmise that for those for whom religion is an important boundary marker, as it is for many SGKAPs, racial intermarriage may be influenced by their interpretation of their ethnic or racial identity in view of their religious identity. In some instances, ethnic or racial endogamy might be preferable on religious grounds, and in other cases intermarriage might be preferable on different religious grounds. Drawing together the observations by Min (2010) and Kim (2010), I propose that:

H4: SGKAPs who were raised as Protestant and currently attend a church where Koreans (or Asians) dominate will exhibit a greater preference for racial endogamy.

H5: SGKAPs who were raised as Protestant and currently attend a church where Koreans (or Asians) dominate will be less intermarried.

These hypotheses in short predict that SGKAPs who are ethnically insular in their religious upbringing and current religious participation will have additional effects on their attitudes and marital choices. Min (2010) and Kim (2010) and others have independently shown that Protestant Korean immigrants socialize their children to marry co-ethnics. Indeed, Kim's observations suggest that SGKAPs see second-generation congregations as meeting spaces for mate selection (2010, pp. 78-80). Given that these 
congregations are predominantly Korean (and in some cases have a contingent of other Asian-American Christians), the dating and marriage market is racialized (2010, pp. 151-3).

\section{Data and Methods}

The Immigration and Intergenerational Mobility in Metropolitan Los Angeles Survey

To examine second-generation Korean-American Protestant insularity patterns, I analyzed data from The Immigration and Intergenerational Mobility in Metropolitan Los Angeles Survey 2003, a regional probability survey with large oversamples of young second-generation residents in southern California (see Rumbaut et al. 2008). Given the significant AsianAmerican presence in Los Angeles, the IMMLA is sufficiently large enough to make comparisons between ethnic groups as well as between racial groups. The full sample consists of 4,655 respondents who ranged in age from 20 to 40 and reported to be the children of immigrants. These include the "1.5 generation," those who moved to the U.S. prior to the age of 12 or were effectively raised in the U.S. (Portes and Zhou 1993). In early analyses, I discovered that about four percent of the sample immigrated to the U.S. after the age of 12. To maintain consistency with previous research, I excluded these respondents and combined the 1.5- generation with the secondgeneration respondents since the size of the generational subsample across ethnic groups varied considerably. The IMMLA sample also contains comparison groups of similarly-aged white non-Hispanic and AfricanAmerican non-Hispanic respondents who are mostly third generation and higher (59\% and 91\% for white and African Americans, respectively). The IMMLA dataset is useful relative to the CILS since it contains a large subsample of Korean Americans and a large subsample of Protestants, but it lacks geographic variation, which has been an important control for understanding intermarriage markets (Harris and Ono 2005). Lacking this control, future research should consider these results in conjunction with social environment factors. 


\section{Dependent Variables}

Religious Retention: The IMMLA asked respondents for their current religious affiliation, which included seven items: Protestant, Catholic, Mormon, Jewish, Muslim, Buddhist, None/Atheist, and Other. For the sake of parsimony, these categories were collapsed into Protestant $(\mathrm{N}=1630)$, Catholic $(\mathrm{N}=1555)$, Buddhist $(\mathrm{N}=256)$, Other $(\mathrm{N}=388)$, and None/Atheist $(\mathrm{N}=622)$, since few second-generation Asian-American respondents identified as Mormon, Jewish, or Muslim. A follow-up question asked Protestant and "Other Christian" respondents whether they considered themselves "born-again," a well-established indicator of evangelical identity. I divided the Protestant sample along these lines to emulate the RELTRAD method for classifying religious affiliations (Steensland et al. 2000). Thus the Protestant affiliation category is divided into "Protestant evangelical" $(\mathrm{N}=1076)$ and "Protestant non-evangelical" $(\mathrm{N}=554)$. Respondents were then asked whether their religious affiliation growing up was the same as the one they identify with at the time of the survey. For those who responded in the negative, they too were asked what their religious affiliation was while growing up, using the same categories mentioned earlier. These categories were similarly collapsed to mirror the current affiliation categories. With this information, we can determine the percentage of "consistent believers," "switchers," and "religious dropouts." Religious retention then was coded "1" where respondents affirmed the same affiliation both at the time of the survey and the affiliation they reported while growing up (i.e. "consistent believers") and switchers and dropouts were recoded as 0 .

Language retention: As a marker of ethnic identity retention, respondents were asked: "When you were growing up, did you ever speak a language other than English at home?" Those who answered in the affirmative $(\mathrm{N}=2810)$ were then asked four follow-up questions regarding their current language skill: speech, comprehension, reading, and writing. Each of these were measured on a 4-point Likert scale ranging from "very well" to "not at all." Since these items correlated fairly highly (all at 0.48 or greater), factor analysis confirmed that they collectively identify a language fluency construct with an alpha value of 0.86 . The final scale ranged from 4 ("not fluent in any way") to 16 ("highly fluent").

Racial composition of congregation: For respondents who attended a religious service more than "never," they were subsequently asked, "In 
general, would you say that the people who attend your place of worship are all your race or ethnic group, mostly your race or ethnic group, mixed, or only a few of your race or ethnic group?" Responses were coded for each of these categorical perceptions of racial composition of their congregation where 1 = "all," 2 = "mostly," 3 = "mixed," 4 = "a few." In these analyses, I collapsed the first two categories and contrasted them with a collapse of the second two categories.

Racial preference for marital partner: Respondents were also asked: "How important do you think it is for people who are your race or ethnic group to marry other people who are of the same race or ethnic groupimportant or not important?" Answers were coded dichotomously to reflect the two choices.

Racial intermarriage: Respondents who were married or cohabiting were asked a number of questions regarding their spouse, including their racial and ethnic background. These were coded to match the racial and ethnic categories of the respondent. Given the specific emphasis on SGKAPs, I collapsed Latino second-generation spouses together into a pan-ethnic Latino category.

\section{Independent Variables}

Race and ethnicity were coded in conventional terms for the larger and most multigenerational groups: white non-Hispanic $(\mathrm{N}=693)$ and black nonHispanic $(\mathrm{N}=444)$. Because of the particular focus of this study, I collapsed Latino ethnic groups into the pan-ethnic term "Latino" $(\mathrm{N}=1744)$ while maintaining the distinct Asian ethnic groups that were larger than 100: Chinese $(\mathrm{N}=363)$, Filipino $(\mathrm{N}=383)$, Korean $(\mathrm{N}=371)$, and Vietnamese $(\mathrm{N}=364)$. All other Asian groups were combined into "Other Asian" $(\mathrm{N}=89)$. Age is a 21-point continuous variable of respondents' reported age at the time of the survey, which included 20 to 40 years. Gender was coded dichotomously where $0=$ male and $1=$ female. Respondents' marital status was recoded into a binary variable where $1=$ "currently married or cohabiting" and $0=$ "not currently married or cohabiting."

\section{Results}

Some of the basic characteristics of the sample which are pertinent to our hypotheses are presented in Table 1. For the various Asian ethnic groups, 
nearly all respondents are either 1.5 or second generation. However, 77 percent of Latinos in the sample fit this classification, as well as 41 percent of the white non-Hispanic sample and about 9 percent of black non-Hispanics surveyed. With respect to early religious socialization, the sample of secondgeneration Korean Americans mirrors the pattern we see in other literature: almost 70 percent of respondents grew up Protestant, while another 14 percent grew up Catholic, 5 percent Buddhist, 2 percent other religion, and 10 percent with no religion. These figures resemble those of young African Americans in the sample, who report 72 percent Protestant heritage and another 14 percent Catholic. In terms of current religious affiliation, the proportion of Protestants is relatively stable for second-generation Korean Americans. Since respondents were asked a question about evangelical belief, I was able to divide the Protestants to roughly determine conservative Protestant identity and non-conservative Protestant identity. As seen in Table 1, of the 68 percent who identify as Protestant, 51 percent would be specifically classified as evangelical, and the remaining 18 percent nonevangelical. This distinction is not evident in any other group, except for African Americans. With respect to marital status, given the average age of the sample, most respondents across all ethnic groups report non-marital status. About 32 percent of second-generation Korean Americans surveyed were either married or cohabiting, the second highest rate following secondgeneration Filipino Americans. In terms of ethnic language facility, less than two-thirds of the sample spoke another language at home besides English while growing up. Second-generation Korean Americans report a fairly high rate of ethnic language use growing up ( 89 percent) while second-generation Chinese and Vietnamese respondents report even higher rates of language use (91 and 94 percent, respectively). Of the one-third that did speak another language besides English, second-generation Korean Americans reported lower mean fluency than the sample average (11.2 compared to 11.8). Indeed this was the case for all second-generation Asian-American groups.

Turning to Table 2, I illustrate the patterns of religious retention by measuring the proportion of early religious affiliation of the respondent to their current affiliation. From this perspective, 85 percent of those growing up as SGKAPs remained Protestant. This is the highest retention rate for the second-generation Korean-American sample. This retention rate is higher than any retention rate for second-generation Chinese Americans and Vietnamese Americans, as well as Latinos and white-non Hispanics. However, second-generation Filipino Protestants and Black non-Hispanic Protestants exhibit slightly higher retention rates. Given this statistical sketch, 


\section{TABLE 1}

Descriptive Statistics of Second-Generation SAmple, IMMLA 2003

$$
(\mathrm{N}=4451)
$$

\begin{tabular}{|c|c|c|c|c|c|c|c|c|c|}
\hline & \multicolumn{8}{|c|}{ Major Ethnic and Racial Groups } & \multirow[b]{2}{*}{ Total } \\
\hline & Korean & Chinese & Vietnamese & Filipino & $\begin{array}{l}\text { Other } \\
\text { Asians }\end{array}$ & Latino & $\begin{array}{c}\text { White } \\
\text { non- } \\
\text { Hispanic }\end{array}$ & $\begin{array}{c}\text { Black } \\
\text { non- } \\
\text { Hispanic }\end{array}$ & \\
\hline \multicolumn{10}{|l|}{ Generation } \\
\hline 1.5 Generation & $60.6 \%$ & $50.1 \%$ & $67.6 \%$ & $44.1 \%$ & $38.2 \%$ & $27.4 \%$ & $10.5 \%$ & $2.5 \%$ & $31.9 \%$ \\
\hline Second generation & $38.8 \%$ & $49.9 \%$ & $32.4 \%$ & $55.9 \%$ & $61.8 \%$ & $49.6 \%$ & $30.7 \%$ & $6.3 \%$ & $40.8 \%$ \\
\hline Third+ generations & $0.5 \%$ & $0.0 \%$ & $0.0 \%$ & $0.0 \%$ & $0.0 \%$ & $23.0 \%$ & $58.7 \%$ & $91.2 \%$ & $27.3 \%$ \\
\hline $\mathrm{N}$ & 371 & 363 & 364 & 383 & 89 & 1744 & 693 & 444 & 4451 \\
\hline \multicolumn{10}{|l|}{ Early Religious } \\
\hline \multicolumn{10}{|l|}{ Affiliation } \\
\hline None & $9.7 \%$ & $28.4 \%$ & $6.9 \%$ & $0.8 \%$ & $13.5 \%$ & $3.2 \%$ & $11.7 \%$ & $5.9 \%$ & $7.7 \%$ \\
\hline Catholic & $13.5 \%$ & $7.2 \%$ & $29.4 \%$ & $83.3 \%$ & $5.6 \%$ & $75.2 \%$ & $29.9 \%$ & $13.5 \%$ & $46.8 \%$ \\
\hline Protestant & $69.8 \%$ & $25.9 \%$ & $6.6 \%$ & $13.3 \%$ & $23.6 \%$ & $18.5 \%$ & $42.6 \%$ & $72.1 \%$ & $31.1 \%$ \\
\hline Buddhist & $4.9 \%$ & $31.4 \%$ & $52.5 \%$ & $1.0 \%$ & $25.8 \%$ & $0.3 \%$ & $0.3 \%$ & $0.2 \%$ & $8.0 \%$ \\
\hline Other non-Christian & $2.2 \%$ & $7.2 \%$ & $4.7 \%$ & $1.6 \%$ & $31.5 \%$ & $2.9 \%$ & $15.6 \%$ & $8.3 \%$ & $6.3 \%$ \\
\hline
\end{tabular}

Current Religious

Affiliation

\begin{tabular}{|c|c|c|c|c|c|c|c|c|c|}
\hline None & $14.8 \%$ & $30.0 \%$ & $17.9 \%$ & $6.5 \%$ & $16.9 \%$ & $10.5 \%$ & $18.5 \%$ & $9.5 \%$ & $14.0 \%$ \\
\hline Catholic & $9.4 \%$ & $5.0 \%$ & $25.3 \%$ & $67.1 \%$ & $3.4 \%$ & $56.5 \%$ & $19.6 \%$ & $6.3 \%$ & $34.9 \%$ \\
\hline Prot. Non- Evang. & $17.5 \%$ & $13.2 \%$ & $3.3 \%$ & $5.7 \%$ & $15.7 \%$ & $9.5 \%$ & $20.2 \%$ & $19.6 \%$ & $12.4 \%$ \\
\hline Prot. Evang. & $51.2 \%$ & $23.1 \%$ & $8.5 \%$ & $17.5 \%$ & $9.0 \%$ & $17.7 \%$ & $21.9 \%$ & $53.2 \%$ & $24.2 \%$ \\
\hline Buddhist & $3.0 \%$ & $17.9 \%$ & $37.9 \%$ & $1.6 \%$ & $21.3 \%$ & $0.5 \%$ & $0.7 \%$ & $0.9 \%$ & $5.8 \%$ \\
\hline Other religions & $4.0 \%$ & $10.7 \%$ & $7.1 \%$ & $1.6 \%$ & $33.7 \%$ & $5.3 \%$ & $19.0 \%$ & $10.6 \%$ & $8.7 \%$ \\
\hline \multicolumn{10}{|l|}{ Marital Status } \\
\hline $\begin{array}{l}\text { Not currently } \\
\text { married/cohabiting }\end{array}$ & $67.7 \%$ & $71.6 \%$ & $74.5 \%$ & $59.8 \%$ & $67.4 \%$ & $51.5 \%$ & $47.6 \%$ & $65.5 \%$ & $58.2 \%$ \\
\hline $\begin{array}{l}\text { Currently married/ } \\
\text { cohabiting }\end{array}$ & $32.3 \%$ & $28.4 \%$ & $25.5 \%$ & $40.2 \%$ & $32.6 \%$ & $48.5 \%$ & $52.4 \%$ & $34.5 \%$ & $41.8 \%$ \\
\hline
\end{tabular}

Ethnic Language

Fluency ${ }^{\mathrm{a}}$

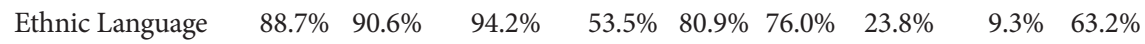
used growing up

$\begin{array}{llllllllll}\text { Mean Fluency }^{\mathrm{b}} & 11.2 & 10.4 & 10.8 & 11.5 & 10.7 & 12.9 & 10.9 & 10.1 & 11.8\end{array}$

\footnotetext{
${ }^{a}$ Reflects those respondents who spoke another English besides English at home while growing up

${ }^{\mathrm{b}}$ Range for fluency: 4 = not fluent at all, 16 = fluent in speech, writing, comprehension, reading
} 
TABLE 2

Percentage of Current Affiliation by Early Religious Affiliation, IMMLA 2003

\begin{tabular}{|c|c|c|c|c|c|c|c|}
\hline \multirow{2}{*}{$\begin{array}{l}\text { Race/ } \\
\text { Ethnicity of } \\
\text { Respondent }\end{array}$} & \multirow{2}{*}{$\begin{array}{l}\text { R's Current } \\
\text { Relig. } \\
\text { Affiliation }\end{array}$} & \multicolumn{5}{|c|}{ Respondent's Religious Affiliation while growing up } & \multirow[b]{2}{*}{ Total } \\
\hline & & None & Catholic & Protestant & Buddhist & $\begin{array}{l}\text { Other non- } \\
\text { Christian }\end{array}$ & \\
\hline \multirow[t]{5}{*}{ Korean } & None & $38.9 \%$ & $14.0 \%$ & $10.4 \%$ & $33.3 \%$ & $12.5 \%$ & $14.8 \%$ \\
\hline & Catholic & $2.8 \%$ & $62.0 \%$ & $1.2 \%$ & & & $9.4 \%$ \\
\hline & Protestant & $55.6 \%$ & $20.0 \%$ & $84.9 \%$ & $27.8 \%$ & & $68.7 \%$ \\
\hline & Buddhist & & & $1.2 \%$ & $38.9 \%$ & $12.5 \%$ & $3.0 \%$ \\
\hline & Other & $2.8 \%$ & $4.0 \%$ & $2.3 \%$ & & $75.0 \%$ & $4.0 \%$ \\
\hline \multirow[t]{5}{*}{ Chinese } & None & $59.2 \%$ & $11.5 \%$ & $11.7 \%$ & $24.6 \%$ & $23.1 \%$ & $30.0 \%$ \\
\hline & Catholic & $1.9 \%$ & $57.7 \%$ & & $0.9 \%$ & & $5.0 \%$ \\
\hline & Protestant & $26.2 \%$ & $15.4 \%$ & $79.8 \%$ & $20.2 \%$ & $11.5 \%$ & $36.4 \%$ \\
\hline & Buddhist & $3.9 \%$ & $3.8 \%$ & $4.3 \%$ & $46.5 \%$ & $11.5 \%$ & $17.9 \%$ \\
\hline & Other & $8.7 \%$ & $11.5 \%$ & $4.3 \%$ & $7.9 \%$ & $53.8 \%$ & $10.7 \%$ \\
\hline \multirow[t]{5}{*}{ Vietnamese } & None & $68.0 \%$ & $7.5 \%$ & $12.5 \%$ & $18.3 \%$ & $11.8 \%$ & $17.9 \%$ \\
\hline & Catholic & $4.0 \%$ & $82.2 \%$ & $4.2 \%$ & $1.0 \%$ & & $25.3 \%$ \\
\hline & Protestant & $8.0 \%$ & $5.6 \%$ & $79.2 \%$ & $8.4 \%$ & & $11.8 \%$ \\
\hline & Buddhist & $16.0 \%$ & $0.9 \%$ & $4.2 \%$ & $68.6 \%$ & $5.9 \%$ & $37.9 \%$ \\
\hline & Other & $4.0 \%$ & $3.7 \%$ & & $3.7 \%$ & $82.4 \%$ & $7.1 \%$ \\
\hline \multirow[t]{5}{*}{ Filipino } & None & $100.0 \%$ & $5.3 \%$ & $7.8 \%$ & & $16.7 \%$ & $6.5 \%$ \\
\hline & Catholic & & $79.9 \%$ & $3.9 \%$ & & & $67.1 \%$ \\
\hline & Protestant & & $12.9 \%$ & $88.2 \%$ & $25.0 \%$ & $33.3 \%$ & $23.2 \%$ \\
\hline & Buddhist & & $0.9 \%$ & & $75.0 \%$ & & $1.6 \%$ \\
\hline & Other & & $0.9 \%$ & & & $50.0 \%$ & $1.6 \%$ \\
\hline \multirow[t]{5}{*}{ Other Asians } & None & $50.0 \%$ & $40.0 \%$ & $4.8 \%$ & $17.4 \%$ & $7.1 \%$ & $16.9 \%$ \\
\hline & Catholic & & $60.0 \%$ & & & & $3.4 \%$ \\
\hline & Protestant & $33.3 \%$ & & $76.2 \%$ & $8.7 \%$ & & $24.7 \%$ \\
\hline & Buddhist & $8.3 \%$ & & $4.8 \%$ & $73.9 \%$ & & $21.3 \%$ \\
\hline & Other & $8.3 \%$ & & $14.3 \%$ & & $92.9 \%$ & $33.7 \%$ \\
\hline \multirow[t]{5}{*}{ Latino } & None & $50.0 \%$ & $8.9 \%$ & $11.2 \%$ & $20.0 \%$ & $2.0 \%$ & $10.5 \%$ \\
\hline & Catholic & $8.9 \%$ & $73.1 \%$ & $6.2 \%$ & $20.0 \%$ & $4.0 \%$ & $56.5 \%$ \\
\hline & Protestant & $28.6 \%$ & $14.6 \%$ & $79.2 \%$ & & $22.0 \%$ & $27.2 \%$ \\
\hline & Buddhist & & $0.3 \%$ & $0.3 \%$ & $60.0 \%$ & & $0.5 \%$ \\
\hline & Other & $12.5 \%$ & $3.1 \%$ & $3.1 \%$ & & $72.0 \%$ & $5.3 \%$ \\
\hline \multirow{5}{*}{$\begin{array}{l}\text { White non- } \\
\text { Hispanic }\end{array}$} & None & $56.8 \%$ & $16.9 \%$ & $13.6 \%$ & & $6.5 \%$ & $18.5 \%$ \\
\hline & Catholic & $6.2 \%$ & $60.4 \%$ & $0.7 \%$ & $50.0 \%$ & $2.8 \%$ & $19.6 \%$ \\
\hline & Protestant & $18.5 \%$ & $14.5 \%$ & $78.0 \%$ & & $15.7 \%$ & $42.1 \%$ \\
\hline & Buddhist & & $0.5 \%$ & $1.0 \%$ & $50.0 \%$ & & $0.7 \%$ \\
\hline & Other & $18.5 \%$ & $7.7 \%$ & $6.8 \%$ & & $75.0 \%$ & $19.0 \%$ \\
\hline \multirow{5}{*}{$\begin{array}{l}\text { Black non- } \\
\text { Hispanic }\end{array}$} & None & $30.8 \%$ & $10.0 \%$ & $7.8 \%$ & & $8.1 \%$ & $9.5 \%$ \\
\hline & Catholic & $3.8 \%$ & $43.3 \%$ & $0.3 \%$ & & & $6.3 \%$ \\
\hline & Protestant & $61.5 \%$ & $33.3 \%$ & $86.9 \%$ & & $24.3 \%$ & $72.7 \%$ \\
\hline & Buddhist & & & $0.6 \%$ & $100.0 \%$ & $2.7 \%$ & $0.9 \%$ \\
\hline & Other & $3.8 \%$ & $13.3 \%$ & $4.4 \%$ & & $64.9 \%$ & $10.6 \%$ \\
\hline \multirow[t]{6}{*}{ Total } & None & $53.5 \%$ & $9.4 \%$ & $10.6 \%$ & $20.7 \%$ & $8.2 \%$ & $14.0 \%$ \\
\hline & Catholic & $4.4 \%$ & $72.0 \%$ & $2.1 \%$ & $1.4 \%$ & $1.8 \%$ & $34.9 \%$ \\
\hline & Protestant & $29.2 \%$ & $14.5 \%$ & $82.1 \%$ & $13.1 \%$ & $15.0 \%$ & $36.6 \%$ \\
\hline & Buddhist & $2.6 \%$ & $0.5 \%$ & $1.1 \%$ & $60.3 \%$ & $2.1 \%$ & $5.8 \%$ \\
\hline & Other & $10.2 \%$ & $3.6 \%$ & $4.1 \%$ & $4.5 \%$ & $72.9 \%$ & $8.7 \%$ \\
\hline & & $100.0 \%$ & $100.0 \%$ & $100.0 \%$ & $100.0 \%$ & $100.0 \%$ & $100.0 \%$ \\
\hline
\end{tabular}


TABLE 3

Percentage Speaking Ethnic Language while Growing Up by Early Religious Affiliation, IMMLA 2003

\begin{tabular}{lcccccc}
\hline \hline \multirow{2}{*}{\begin{tabular}{c} 
Race/ Ethnicity of $\begin{array}{c}c \\
\text { Respondent }\end{array}$ \\
\cline { 2 - 6 }
\end{tabular}} & None & Catholic & Protestant & Buddhist & $\begin{array}{c}\text { Other } \\
\text { Religions }\end{array}$ & \\
\hline Korean & $88.9 \%$ & $94.0 \%$ & $88.0 \%$ & $94.4 \%$ & $62.5 \%$ & $88.7 \%$ \\
Chinese & $89.3 \%$ & $84.6 \%$ & $87.2 \%$ & $95.6 \%$ & $92.3 \%$ & $90.6 \%$ \\
Vietnamese & $88.0 \%$ & $95.3 \%$ & $83.3 \%$ & $95.8 \%$ & $94.1 \%$ & $94.2 \%$ \\
Filipino & $33.3 \%$ & $53.9 \%$ & $45.1 \%$ & $100.0 \%$ & $83.3 \%$ & $53.5 \%$ \\
Other Asians & $66.7 \%$ & $80.0 \%$ & $76.2 \%$ & $87.0 \%$ & $85.7 \%$ & $80.9 \%$ \\
Latino & $64.3 \%$ & $79.9 \%$ & $63.7 \%$ & $60.0 \%$ & $70.0 \%$ & $76.0 \%$ \\
White non-Hispanic & $15.0 \%$ & $31.9 \%$ & $17.3 \%$ & $50.0 \%$ & $32.4 \%$ & $23.8 \%$ \\
Black non-Hispanic & $11.5 \%$ & $11.7 \%$ & $8.5 \%$ & & $10.8 \%$ & $9.3 \%$ \\
\hline Total & $60.4 \%$ & $70.4 \%$ & $47.1 \%$ & $94.1 \%$ & $52.9 \%$ & $63.2 \%$ \\
\hline
\end{tabular}

I cannot confirm hypothesis 1 , which states that SGKAPs are more likely to retain their religious affiliation more so than other religious secondgeneration Asian Americans or African Americans.

With regard to hypothesis 2 on SGKAP language retention, an ANOVA test of the mean fluency differences between second-generation AsianAmerican groups (as well as Latinos, and black and white non-Hispanics) revealed that second-generation Korean Americans are not less likely to lose fluency of their parents' ethnic tongue relative to other groups. Moreover, subsequent analyses show that SGKAPs are not less likely to be fluent in Korean relative to other second-generation Korean nonaffiliates, Catholics, and Buddhists. Even when we account for specific evangelical affiliation or childhood religious affiliation, we find no statistical differences in language retention. Thus I find no support for hypothesis 2.

Turning to hypothesis 3 regarding SGKAP church homophily, I find that most evangelical SGKAPs attend a congregation that is "mostly or all the same ethnic group" as themselves (about 73 percent). This is the highest rate among religious second-generation Korean Americans. SGKAPs are not unique in homogeneous church attendance. Second-generation KoreanAmerican non-evangelical Protestants, and Buddhists (56 and 60 percent, respectively), Chinese- and Vietnamese-American Buddhists (75 and 85 percent, respectively), as well as Chinese-American evangelical Protestants (56 percent) also attend religious organizations comprised predominantly or 
TABLE 4

Percentage of Religious Affiliates Attending Religious Congregation of the Same Race or Ethnicity as the Respondent, IMMLA 2003

\begin{tabular}{lcccccc}
\hline \hline & \multicolumn{5}{c}{ Current Religious Affiliation } \\
\cline { 2 - 7 } \multicolumn{1}{c}{$\begin{array}{c}\text { Race/ Ethnicity of } \\
\text { Respondent }\end{array}$} & $\begin{array}{c}\text { Catholic } \\
\text { Protestant } \\
\text { Non } \\
\text { Evangelical }\end{array}$ & $\begin{array}{c}\text { Protestant } \\
\text { Evangelical }\end{array}$ & Buddhist & $\begin{array}{c}\text { Other } \\
\text { religions }\end{array}$ & Total \\
\hline Korean & $31.2 \%$ & $55.8 \%$ & $72.7 \%$ & $60.0 \%$ & $71.4 \%$ & $64.4 \%$ \\
Chinese & $26.7 \%$ & $41.9 \%$ & $56.1 \%$ & $75.0 \%$ & $43.8 \%$ & $55.6 \%$ \\
Vietnamese & $33.3 \%$ & $36.4 \%$ & $45.2 \%$ & $85.2 \%$ & $46.2 \%$ & $59.0 \%$ \\
Filipino & $16.2 \%$ & $31.6 \%$ & $27.7 \%$ & $50.0 \%$ & $20.0 \%$ & $19.7 \%$ \\
Other Asians & --- & $41.7 \%$ & $28.6 \%$ & $73.3 \%$ & $51.9 \%$ & $51.6 \%$ \\
Latino & $43.8 \%$ & $28.1 \%$ & $26.9 \%$ & --- & $30.1 \%$ & $37.9 \%$ \\
White non-Hispanic & $17.5 \%$ & $37.4 \%$ & $30.8 \%$ & --- & $51.9 \%$ & $32.3 \%$ \\
Black non-Hispanic & $14.8 \%$ & $42.2 \%$ & $46.5 \%$ & $25.0 \%$ & $20.0 \%$ & $40.3 \%$ \\
\hline
\end{tabular}

exclusively of members of their own ethnicity or race. Due to the smaller presence of American Buddhists, it is surprising that ethnic/racial homogeneity is as high as it is for these subgroups. Some research suggests that non-Christian religious communities are the most diverse and that Buddhists in particular make strong efforts to attract non-Asian members. ${ }^{6}$ That issue aside, it bears noting that three second-generation Korean religious groups, two of whom are Protestant, have majority shares of respondents attending ethno-racial homogeneous religious organizations. In other words, religious homophily may be a distinctive characteristic of religious second-generation Korean Americans, and among them, SGKAPs are the most homophilous. Thus we find some support for hypothesis $3{ }^{7}$

With respect to same-race marital preference among the second generation, Korean Americans stand apart as well. While a minority of respondents regardless of ethnicity, race, or religion affirmed the importance

${ }^{6}$ Emerson and Woo (2006) found non-Christian religious traditions were the most diverse; Yang (2000) observed that immigrant Chinese Buddhists actively recruit white and other non-Chinese Americans to participate in their temples.

${ }^{7}$ Further analyses using childhood religious affiliation reveals a similar pattern. About 70 percent of second-generation Korean Americans who were raised Protestant currently attends an Asian or Korean-dominant congregation. This is the highest percentage of all Christian respondents regardless of Asian ethnicity and racial statuses. The next highest are second-generation Vietnamese Americans who were raised Protestant; 57 percent currently attend an Asian or Vietnamesedominant congregation. 
of endogamy, the largest and most consistent minority responses appear among the second-generation Korean Americans. About 28 percent of those who grew up Protestant affirmed racial/ethnic endogamy; this is higher than any other ethnic or racial Protestant-raised group in the sample, and the highest among the second-generation Korean-American subsample. The only other group with a comparable figure was among young African Americans, who grew up Catholic (29 percent). Apart from this one exception, we have some support for hypothesis 4, SGKAPs who were raised Protestant exhibit a greater preference for endogamy.

Coupled with higher preference for ethnic/racial endogamy are the actual rates of endogamous marriages among second-generation Korean Americans, and particularly SGKAPs. In Table 5, we find that secondgeneration Korean Americans have the highest endogamy rate of all Asian groups, but they are on par with Latinos, African Americans, and white Americans. When we look more closely at the religious differences within each ethnic and racial category, we find that SGKAPs have the highest endogamy rate compared to all other young and married Protestants in the sample; more than 82 percent report being in an endogamous relationship. Married African-American Protestants are the next highest at 76 percent. In addition, compared to all other married second-generation Korean Americans, married SGKAPs are the most endogamous as well. Married second-generation Korean Buddhists are the second highest at 60 percent. This pattern holds when we subdivide the Protestants between evangelical and non-evangelical. Almost 84 percent of married evangelical SGKAPs are in ethnically endogamous relationships, the highest rate of all married second-generation Korean Americans, and all married Protestants (both evangelical and non-evangelical) in the sample. Further, this ranking is repeated when we compare SGKAPs with others based on their religion of origin, illustrated in Table $5 .{ }^{8}$

The hypothesis I proposed specifically accounted for current religious attendance that was also predominantly Asian or Korean and religious socialization in a presumably immigrant-ethnic dominant context. In Table 5 we find that almost 74 percent of married SGKAPs who grew up Protestant attend a congregation they perceive to be Korean or Asian dominant. This is second only to married second-generation Vietnamese-American

${ }^{8}$ Almost 77 percent of married second-generation Korean Americans raised as Protestants have a Korean spouse. This is the highest for all married second-generation Korean American respondents, and second highest for all second-generation Protestants (second-generation Vietnamese American Protestants have an 80 percent endogamy rate). 


\section{TABLE 5}

Percentage Affirming the Importance of Endogamy and Percent ENDogamous by Early Religious AfFiliation, IMMLA 2003

\begin{tabular}{|c|c|c|c|c|c|c|c|}
\hline & \multirow{2}{*}{$\begin{array}{l}\text { Race/ Ethnicity of } \\
\text { Respondent }\end{array}$} & \multicolumn{5}{|c|}{ Religious Affiliation While Growing Up } & \multirow[b]{2}{*}{ Total } \\
\hline & & None & Catholic & Protestant & Buddhist & $\begin{array}{c}\text { Other } \\
\text { Religions }\end{array}$ & \\
\hline \multirow{8}{*}{$\begin{array}{l}\text { Affirming } \\
\text { the } \\
\text { Importance } \\
\text { of } \\
\text { Endogamy }\end{array}$} & Korean & $25.7 \%$ & $24.0 \%$ & $28.2 \%$ & $22.2 \%$ & & $26.5 \%$ \\
\hline & Chinese & $12.9 \%$ & $11.5 \%$ & $15.1 \%$ & $18.4 \%$ & $16.7 \%$ & $15.4 \%$ \\
\hline & Vietnamese & $12.0 \%$ & $16.0 \%$ & $12.5 \%$ & $19.3 \%$ & $26.7 \%$ & $17.6 \%$ \\
\hline & Filipino & & $11.4 \%$ & $7.8 \%$ & $25.0 \%$ & $16.7 \%$ & $11.0 \%$ \\
\hline & Other Asians & & $20.0 \%$ & & $13.6 \%$ & $32.1 \%$ & $14.8 \%$ \\
\hline & Latino & $21.4 \%$ & $15.8 \%$ & $16.2 \%$ & $20.0 \%$ & $16.0 \%$ & $16.1 \%$ \\
\hline & White non-Hispanic & $10.0 \%$ & $10.6 \%$ & $11.3 \%$ & $50.0 \%$ & $14.8 \%$ & $11.6 \%$ \\
\hline & Black non-Hispanic & $16.0 \%$ & $28.8 \%$ & $19.5 \%$ & & $29.7 \%$ & $21.4 \%$ \\
\hline Endogamy & Korean & $69.2 \%$ & $53.3 \%$ & $76.5 \%$ & $75.0 \%$ & $33.3 \%$ & $71.7 \%$ \\
\hline \multirow{7}{*}{ Rate } & Chinese & $56.7 \%$ & $100.0 \%$ & $65.5 \%$ & $73.1 \%$ & $50.0 \%$ & $65.3 \%$ \\
\hline & Vietnamese & $33.3 \%$ & $86.7 \%$ & $80.0 \%$ & $31.1 \%$ & $60.0 \%$ & $53.8 \%$ \\
\hline & Filipino & $50.0 \%$ & $43.5 \%$ & $35.0 \%$ & & & $42.5 \%$ \\
\hline & Other Asians & $75.0 \%$ & $66.7 \%$ & $66.7 \%$ & $45.5 \%$ & & $55.2 \%$ \\
\hline & Latino & $68.4 \%$ & $75.5 \%$ & $71.5 \%$ & & $60.0 \%$ & $74.0 \%$ \\
\hline & White non-Hispanic & $75.7 \%$ & $70.2 \%$ & $72.7 \%$ & $100.0 \%$ & $63.5 \%$ & $70.7 \%$ \\
\hline & Black non-Hispanic & $83.3 \%$ & $62.5 \%$ & $73.1 \%$ & $100.0 \%$ & $72.7 \%$ & $73.0 \%$ \\
\hline
\end{tabular}

TABLE 6

Percentage of Married Second-Generation Attending Same-Race/ Ethnic Dominant Religious Organization by Religious AfFiliation WHILE GROWING UP, IMMLA 2003

\begin{tabular}{lccccc}
\hline \hline & \multicolumn{4}{c}{ Religious Affiliation while Growing Up } \\
\cline { 2 - 6 } $\begin{array}{c}\text { Race/ Ethnicity of } \\
\text { Respondent }\end{array}$ & Catholic & Protestant & Buddhist & $\begin{array}{c}\text { Other non- } \\
\text { Christian }\end{array}$ & Total \\
\hline Korean & $42.9 \%$ & $73.7 \%$ & $66.7 \%$ & & $69.7 \%$ \\
Chinese & $75.0 \%$ & $58.8 \%$ & $63.6 \%$ & $50.0 \%$ & $64.3 \%$ \\
Vietnamese & $29.2 \%$ & $100.0 \%$ & $66.7 \%$ & & $45.2 \%$ \\
Filipino & $12.5 \%$ & $66.7 \%$ & & & $17.7 \%$ \\
Other Asians & & $60.0 \%$ & $25.0 \%$ & & $41.7 \%$ \\
Latino & $39.5 \%$ & $47.5 \%$ & & $26.7 \%$ & $40.5 \%$ \\
White non-Hispanic & $20.0 \%$ & $41.6 \%$ & & $57.7 \%$ & $36.4 \%$ \\
Black non-Hispanic & $50.0 \%$ & $42.9 \%$ & $100.0 \%$ & $33.3 \%$ & $43.5 \%$ \\
\hline Total & $35.3 \%$ & $51.6 \%$ & $61.3 \%$ & $43.4 \%$ & $42.1 \%$ \\
\hline
\end{tabular}


Protestants-all of them report attendance at an Asian- or Vietnamesedominant congregation. I should note that this latter figure is based on only four respondents, who met all the specific criteria, whereas the Korean Protestant figure is based on 57 cases. That exception aside, married religious SGKAPs in endogamous marriages are much more likely to be in Korean- or Asian-dominant congregations. Thus we find some support for hypothesis 5.

\section{Second-Generation Korean-American Protestant Exceptionalism}

In the previous analyses, I proposed five hypotheses of ethnic/racial insularity for second-generation Korean Americans. Given their greater access to multicultural American values and their general socialization in ethnic-dominant religious congregations, it is unclear whether religious retention as well as ethnic retention and racial homogamy would persist for this group. My findings suggest that SGKAP religious retention does not differ all that much from other religious second-generation respondents in this sample. Their relative fluency with the preferred language of their immigrant parents differs little from other second-generation young adults. However some evidence suggests that SGKAPs are generally more insular in their ethnic/racial religious networks and in their racial/ethnic preferences for marital partners. Finally, among married SGKAPs, we also see greater religious network homogamy relative to other groups. In short, their religious and ethnic ties do not vary a great deal from their peers who are experiencing analogous social contexts and pressures to conform; however their behaviors that stem from those ties are more consistently homophilous and endogamous. This suggests that perhaps the second-generation KoreanAmerican Protestant case is somewhat exceptional in our diversifying environment. While their congregations may cater to an English-fluent audience, their congregations are noticeably uniform in racial and ethnic terms. Tentatively, I suggest that religion serves to sacralize ethnic/racial preference for second-generation Korean Americans more so than other groups. Why might this particular combination stand apart from others?

Perhaps the most evident explanation might be location. This study is based on data drawn from the southern California context, a unique context for second-generation Korean Americans. With a very large population of Korean Americans, some of these homogenizing patterns may be the result of greater availability of similar ethnic peers and potential spouses. Further 
research should consider exploring these patterns in other contexts where Korean Americans are fewer in number, and where the opportunities to find a marital spouse with the same ethnicity or participate in a secondgeneration congregation are scarce.

Apart from methodological improvements, this pattern may be reflective of a curious dynamic that might help generate the relationships observed above. Perhaps the mass exposure to evangelical Protestant culture within Korean America is such that it demands integration between a theology that emphasizes the exclusive religious identity and an ethnic culture that emphasizes collective identity. The dominant presence of evangelical culture ensures limited exposure to alternative possibilities of combining religious orientations with ethnic-cultural identity.

For example, evangelical Chinese-American Protestants comprise a much smaller fraction of the Chinese-American population. Chinese America consists of a larger proportion of individuals who report no religion or Buddhism as their religious preference. Thus the likelihood of encountering other Chinese Americans who understand religion and ethnicity in different ways is much greater. Such exposure presents new information for an emerging second-generation Chinese evangelical to deliberate her or his identities. Unlike second-generation Korean-American evangelicals, they may conclude that identity maintenance does not necessarily imply greater endogamy and religious racial homophily.

The Filipino Catholic case is another example. Like the Korean Protestant case, this ethnic-religious combination dominates the social landscape of the Filipino-American population. But since Catholic theology is less exclusive than evangelicalism, it does not serve as a consolidating schema that bundles ethnicity with faith. Thus while a western religion dominates this Asian-American group, it does not result in greater endogamy and religious group homophily.

Taken together, second-generation Korean-American Protestantism poses an important case study in the relationship between race and religion for new and emerging minorities in the United States. As more secondgeneration Protestant communities emerge, perhaps we are witnessing the development of a new religious tradition that resembles to a much smaller extent the African-American Protestant tradition. In both cases, their theological commitments resemble that of white evangelical Protestantism but develop in relative isolation from it. Within these mono-ethnic or monoracial environments, ethnic-religious identities emerge which engender social replication via same-race congregations and a propensity to marry within the 
ethno-religious community.

\section{References}

Abelmann, Nancy. 2009. The Intimate University: Korean American Students and the Problems of Segregation. Durham, NC: Duke University Press.

Alumkal, Antony W. 1999. "Preserving Patriarchy: Assimilation, Gender Norms, and Second-Generation Korean American Evangelicals." Qualitative Sociology 22(2):127-40.

Alumkal, Antony W. 2003. Asian American Evangelical Churches: Race, Ethnicity, and Assimilation in the Second Generation. New York: LFB Scholarly Publishing.

Blau, Peter M. 1977. Inequality and Heterogeneity: A Primitive Theory of Social Structure. New York: Free Press.

Busto, Rudy V. 1996. "The Gospel According to the Model Minority?: Hazarding an Interpretation of Asian American Evangelical College Students." Amerasia Journal 22(1):133-47.

Chong, Kelly H. 1998. "What it Means to be Christian: The Role of Religion in the Construction of Ethnic Identity and Boundary Among Second-Generation Koreans." Sociology of Religion 59(3):259-86.

Ecklund, Elaine Howard. 2006. Korean American Evangelicals: New Models for Civic Life. New York: Oxford University Press.

Emerson, Michael O., and Rodney Woo. 2006. People of the Dream: Multiracial Congregations in the United States. Princeton: Princeton University Press.

Harris, David R., and Hiromi Ono. 2005. "How Many Interracial Marriages Would There Be If All Groups Were of Equal Size in All Places? A New Look at National Estimates of Interracial Marriage." Social Science Research 34(1):236-51.

Hollinger, David A. 1995. Postethnic America: Beyond Multiculturalism. New York: Basic Books.

Jeung, Russell. 2005. Faithful Generations: Race and New Asian American Churches. New Bunswick and London: Rutgers University Press.

Kalmijn, Matthijs. 1998. "Intermarriage and Homogamy: Causes, Patterns, Trends." Annual Review of Sociology 24:395-421.

Kim, Rebecca Y. 2004. "Second-Generation Korean American Evangelicals: Ethnic, Multiethnic, or White Campus Ministries?” Sociology of Religion 65(1):19-34.

Kim, Rebecca Y. 2006. God's New Whiz Kids? Korean American Evangelicals on Campus. New Brunswick, NJ: Rutgers University Press.

Kim, Sharon. 2010. A Faith of Our Own: Second-Generation Spirituality in Korean American Churches. New Brunswick, NJ: Rutgers University Press.

Le, C. N. 2012. "Interracial Dating \& Marriage." Asian-Nation: The Landscape of Asian America. http://www.asian-nation.org/interracial.shtml. Date Accessed: 
March 20, 2013.

Marti, Gerardo. 2005. A Mosaic of Believers: Diversity and Innovation in a Multiethnic Church. New Brunswick: Rutgers University Press.

Min, Pyong Gap. 1992. "The Structure and Social Functions of Korean Immigrant Churches in the United States." International Migration Review 26(4):1370-94.

Min, Pyong Gap. 2010. Preserving Ethnicity Through Religion in America: Korean Protestants and Indian Hindus Across Generations. New York: New York University Press.

Min, Pyong Gap, and Chigon Kim. 2009. "Patterns of Intermarriages and CrossGenerational In-Marriages among Native-Born Asian Americans.” International Migration Review 43(3):447-70.

Morgan, Charlie V. 2012. "Toward a More Nuanced Understanding of Intercoupling: Second-Generation Mixed Couples in Southern California." Journal of Family Issues 33:1423-49.

Muse, Erika A. 2005. The Evangelical Church in Boston's Chinatown: A Discourse of Language, Gender, and Identity. New York: Routledge.

Park, Jerry Z. 2012. "Racial Insularity and Ethnic Faith: The Emerging Korean American Religious Elite.” Pp. 135-55 in Sustaining Faith Traditions: Race, Ethnicity, and Religion Among the Latino and Asian American Second Generation, edited by Carolyn Chen and Russell Jeung. New Brunswick, NJ: Rutgers University Press.

Park, Soyoung. 2004. “Korean American Evangelical' A Resolution of Sociological Ambivalence Among Korean American College Students." Pp. 182-204 in Asian American Religions: The Making and Remaking of Borders and Boundaries, edited by Tony Carnes and Fenggang Yang. New York: New York University Press.

Portes, Alejandro, and Min Zhou. 1993. “The New Second Generation: Segmented Assimilation and Its Variants Among Post-1965 Immigrant Youth." Annals of the American Academy of Political and Social Science 530(November):74-96.

Qian, Zhenchao, and Daniel T. Lichter. 2007. "Social Boundaries and Marital Assimilation: Interpreting Trends in Racial and Ethnic Intermarriage." American Sociological Review 72(1):68-94.

Qian, Zhenchao, and Daniel T. Lichter. 2011. "Changing Patterns of Interracial Marriage in a Multiracial Society." Journal of Marriage and Family 11:1065-84.

Rumbaut, Ruben G. et al. 2008. Immigration and Intergenerational Mobility in Metropolitan Los Angeles (IIMMLA), 2004. ICPSR22627-v1. Ann Arbor, MI: Inter-university Consortium for Political and Social Research [distributor].

Steensland, Brian et al. 2000. "The Measure of American Religion: Toward Improving the State of the Art." Social Forces 79(1):291-318.

Taylor, Paul et al. 2010. Marrying Out: One-in-Seven New US Marriages is Interracial or Interethnic. Washington DC: Pew Research Center Social and Demographic Trends.

Taylor, Paul et al. 2012. The Rise of Asian Americans. Washington DC: Pew Research 
Center Social and Demographic Trends.

Yang, Fenggang. 2000. “The Hsi-Nan Chinese Buddhist Temple: Seeking to Americanize." Pp. 67-87 in Religion and the New Immigrants: Continuities and Adaptations in Immigrant Congregations, edited by Helen R. Ebaugh and Janet S. Chafetz. Walnut Creek, CA: Alta Mira Press.

Yang, Fenggang. 2004. "Gender and Generation in a Chinese Christian Church." Pp. 205-22 in Asian American Religions: The Making and Remaking of Borders and Boundaries, edited by Tony Carnes and Fenggang Yang. New York: New York University Press.

JERRY Z. PARK is an associate professor of sociology at Baylor University. His research interests are in American religion, race relations, social identities, culture and civic engagement. He has published peer-reviewed articles in journals such as Social Forces, The Sociological Quarterly, Journal for the Scientific Study of Religion, Sociological Perspectives, and Journal of Asian American Studies. He is currently studying the religious influences in workplace outcomes and entrepreneurial enterprises through a grant from the National Science Foundation. Address: Baylor University, Department of Sociology, One Bear Place \#97326, Waco, TX 76798-7326 [E-mail: jerry_park@baylor.edu] 